\title{
Giorgio Prodi and the lower threshold of semiotics
}

\section{Umberto Eco ${ }^{1}$}

\begin{abstract}
Publication of a translation of the text of Umberto Eco's talk given in honour of Giorgio Prodi in 1988.
\end{abstract}

Keywords: biosemiotics; immunology; history of semiotics; semiotic threshold

We are here to remember a man of 'multifarious talent' and I must resist the temptation of making it a global praise. If the talent of our deceased friend was multifarious, the praise must be multifarious, yet collective. Today, I propose to recall only the contribution made by Giorgio Prodi to an issue debated within the field of semiotics for a long time. It should be made clear that regarding Giorgio Prodi as a scientist, a scholar and a thinker, today I do not intend to celebrate even just the thinker, the author of books that span from logic to aesthetics, from ethics to the theory of culture. By doing so, one would risk saying that Giorgio Prodi was an exceptional man, which is well known, but one would utter but a heart-warming generality. One can be an exceptional character as St. Francis or Jack the Ripper, and it is undoubtedly exceptional for a man to have cultivated so numerous and so diverse fields of knowledge without being amateurish in any of them. This is why it is important for us to understand what he realized in a specific domain, and, on the basis of that, - and through that, if at all - fairly cast light on the other fields, with no pretence to outline the work of a lifetime in the space of a short account.

\footnotetext{
1 This is the text of Umberto Eco's presentation from 1988, made in honour of the Italian medical scholar and biosemiotician Giorgio Prodi (1928-1987). Its manuscript ("Giorgio Prodi e la soglia inferiore della semiotica") was found among Thomas A. Sebeok's materials on Prodi and is stored at the Thomas A. Sebeok Memorial Library at the Department of Semiotics of the University of Tartu. (See a longer commentary in Kull, Kalevi 2018, Umberto Eco on the biosemiotics of Giorgio Prodi, Sign Systems Studies 46(2/3): 352-364). Translated from Italian and edited by Remo Gramigna, footnotes added and edited by Kalevi Kull. Published with the kind permission of Umberto Eco's family.
} 
Therefore, I will be talking about the issue of the lower threshold of semiotics: how Giorgio Prodi found it and how he lost it.

I am aware of speaking to an audience with a different scientific background, and not to a congress of semioticians, and therefore I will be reasonably popular and reasonably superficial. Please appreciate this, and forgive me at the same time. Thus, although Prodi's literary production is most extensive, I will exclusively refer to three essays (available and readable, not without an effort, but in accessible terms also for the non-specialists), two of which represent his debut in semiotics, and the third - a posthumous one - remaining his testament as a philosopher of culture. These are an essay published in Lingua e Stile in 1974, another published in Versus in 1976, and one that appeared in Intersezioni in 1988. ${ }^{2}$ In addition, I also refer to several books, already well known to specialists.

At least since the Hellenistic period, we mean by semiotics the study of the phenomenon of semiosis, that is to say, the process through which humans emit and interpret signs. According to an ancient definition, a sign is something that stands in the place of something else. Something is present, and in some ways, either due to convention or some relation of homology and/or analogy, it brings something else to us. If this is the definition, verbal language undoubtedly is only one of the forms of semiosis, although the most articulate and powerful one. But semiosis also involves domains in which something has not been intentionally emitted as a sign of something else, yet the interpreter still decides to interpret it as a sign. The activity of the physician who scrutinizes the symptoms of the patient is a semiotic activity as is the one of the hunter who interprets tracks in the wood.

In the mid-1950s, catalyzing a series of suggestions across the entire history of human thought, from philosophy to linguistics, from psychology to anthropology, the vogue of semiotics exploded, as it were, and scholars of diverse disciplines threw themselves into discovering communication processes and underlying signification processes in all domains, from architecture to gestural expressiveness and body postures. In such fervour of discovery it was natural that somebody would seek to identify semiosic processes also among animals (zoosemiotics), among plants (phytosemiotics), as well as at the cellular level. The discovery of the genetic code at the beginning of the $1950 \mathrm{~s}^{3}$ seemed to prove that there were processes of communication also at the heart of the biological.

\footnotetext{
2 See Prodi 1974; 1976; 1988.

3 Strictly speaking, the genetic code (the rules of correspondence between the sequences of nucleic acids and proteins - i.e., between the triplets of iRNA and aminoacids) was discovered only in the 1960s. What was discovered in the early 1950s was the bihelical structure of DNA; the correspondences A-T and C-G in the DNA are not ccode-based, but sterochemical.
} 
Regrettably, the semiotics of the 1960s developed in the pursuit of the most articulate of the semiotic disciplines, linguistics, and the fault of many welldeserving efforts was their attempt to identify the presence of linguistic phenomena in universes that were not linguistic. I will not trace the history of such an illusion and of its failures. If verbal language is, as it certainly is, the most articulate form of semiosis that distinguishes humans from all other beings, how can it ever be expected that animals (or, worse, cells) should behave linguistically? We remained victim of many cases of epistemological trompe-l'oeil. If geneticists told us that a triplet of nitrogen bases GCU referred to - for themselves and for us - the amino acid alanine, how were we to escape an analogy with the relationship of signification that exists between a given sequence of dots and dashes in the Morse code and a letter of the alphabet?

Unfortunately, it was forgotten that the genetic code is not the code that cells themselves "know", but the code, that is to say, the meta-code, that the geneticist elaborates in order to explain what cells "do". A human being faced with a sequence of dots and dashes decides to interpret the sequence as a letter of the alphabet on the basis of an acquired competence - and if he does not know the Morse code he cannot interpret it, or, knowing the Morse code, he can still decide not to interpret it. Biological processes, instead, occur sterically, namely due to the "friction" between two chains, one consisting of holes, the other of protrusions. Due to a blind need, every protrusion fits into a hole, when it finds it. However, it finds the latter if the two fitting strips rub against each other. The protrusion cannot "think" about the hole that pertains to it, nor decide to go and search for it. The relationship that links stimulus to response is also similar: the stimulus blindly triggers the response. ${ }^{4}$ So is it in the conditioned reflex: one could think that the Pavlovian dog "interprets" the bell as a sign of food and "decides" to salivate, but only if it were possible, as it happens in a Russian joke, to imagine a clever dog who goes daily to the Pavlov Institute and salivates in order to induce a conditioned scientist to ring the bell and bring it food. Unfortunately, humans know that a given cause produces a given effect, the effect can be taken as a sign of its invisible cause, but the dog does not. It suffers the cause and secretes the effect.

Personally, at the beginning of the 1970s I opposed such, undoubtedly anthropomorphizing, illicit transpositions of the linguistic model on other phenomena, which I assigned to the lower threshold of semiotics.

4 Here, Eco does not make a distinction between mediated and non-mediated interactions. In case of both the genetic code and the conditioned reflex, the relationship is mediated - i.e., it is not determined according to some general law, but is either phylogenetically or ontogenetically acquired. As far as the mediated relations (codes) are products of semiosis (despite of functioning automatically as worked out habits), these could belong to the sphere of interest of semiotics. 
In order to understand the issue better - and I quote an author that Prodi knew well - we may go back to Charles Sanders Peirce, one of the founding fathers of modern semiotics. Every relationship with the world is marked by three phases that may never be completed: firstness, secondness and thirdness. I place my hand on the stove and burn myself: firstness is the moment at which I perceive pain, and I would perceive it even if I had sudden cramps in my intestines without any external agent causing them. Secondness is the moment at which, although still in a confused way, I identify the stove in front of me as the cause of my pain, something that is opposing me. Thirdness is the moment at which I pass to the order of the symbolic and say (and think), "stove", that is to say, "It is the stove that burned me." From this point, I have entered the order of language and thought, and I will also be able to make inferences about what will happen if I bring my hand closer to something that is not that stove, but that may be subsumed under the same category. I entered the order of language because I passed from the particular to the universal. The space that separates secondness and thirdness is the space of semiosis, of interpretation.

My thesis was that between the stimulus (or signal) and the sign there exists just this space precisely. It is possible to speak of animal semiosis or cellular semiosis only if it could be shown that such a space is created also at these levels. One of the last times I had the opportunity of spending a long time with Giorgio Prodi was two years ago, at a congress organized in Lucca $^{6}$ by the leaders of international immunology. By the way, I remember those days because it was then that, sitting at the bar and calmly drinking whiskey, Giorgio Prodi calmly told me about his malaise, about his calm worries and his calm hopes, as was his style.

The leaders of international immunology held that there occurs semiosis and therefore thirdness in immunological processes - but after having promoted this, Jerne, ${ }^{7}$ probably the most eminent immunologist, had sent a message that invited scepticism. They sought to show (and try to forgive me if I am excessively imprecise, but also our immunologist interlocutors indulged in metaphors and analogies) that when a lymphocyte $\mathrm{T}$ recognizes an antigen, it calls other lymphocytes suppressors, effectors and inductors - to collaborate so as to adequately target it with the antibody. A space was hinted at which the lymphocyte could make a

5 Thirdness, according to Peirce, does not necessarily require symbolicity. Thirdness is a dimension of any sign. However, in certain simplified interpretations Eco's statement can be read as correct.

6 The NATO Advanced Research Workshop on the Semiotics of Cellular Communication in the Immune System held at Il Ciocco, Lucca, Italy, 9-12 September 1986. Eco gave a talk there, published as Eco 1988a.

7 Niels Kaj Jerne (1911-1994), a Danish immunologist. 
guess, a hypothesis of recognition, and ultimately a choice. The question posed by semioticians was whether there really was a choice, and whether there was a space, or whether we would once again be faced with key-lock processes, a steric dynamic based on rubbing - and the lymphocyte had no choice. If it had none, there was no thirdness and, therefore, no semiosis. Still, the phantom of that space, on which the immunologists themselves diverged, fascinated all. What if there was such a space, what if a principle of thirdness was already traced down there? However, at least as far as I am concerned, the shortcoming of the immunologists was that they still sought to show that processes of semiosis similar to those of humans occurred at the cellular level.

When, in 1974, Giorgio Prodi visited me for the first time, I was still very suspicious towards every semiotic approach to the cellular universe. But I was struck by the mention of a Copernican revolution that I glimpsed in his talk. For the first time, I was faced with a scientist who was not telling me "maybe cells speak like us", but, rather, "maybe we speak like cells".

In this simple inversion of the terms of the problem lies the originality of Prodi's approach. A profound connoisseur of semiotic problems and of the universe of culture, he did not commit the naivité of supposing that behaviours similar to cultural behaviours would occur at a cellular level. He excluded this from the outset. His problem was rather: since the cultural universe is not born in a vacuum, because it appears if not as the final, then as the most recent result of the evolution of the species, let us go back to where nature is not yet culture, but from where culture, as the terminus of evolution, originates.

A few quotations from an essay from 1976 clarify his thought - or, if you wish, his final attempt. If, until today, we have considered the stimulus as being deprived of a sign, let us now consider it as the beginning. "It seems [...] that to really test a science of signs [...] it is necessary to eliminate any linguistic perspective and any intentional premise" (Prodi 1976: 69). “The elementary sign condition is a physical state whereby a structure bears significance in relation to another structure inasmuch as it selectively interferes with it. A substrate is a sign for an enzyme inasmuch as it is complementary to one of its parts, and therefore appears as meaningful [...]. Glucose-6-phosphate dehydrogenase will recognize glucose6-phosphate as a 'sign partner'. This is a 'sign' for the enzymatic structure [...]. A thing is never an impersonal sign for any reader, but it is a sign for a determined structure, inasmuch as this structure has become adapted to it during evolution [...]. The relationship between the thing as material presence and the thing as sign is therefore only this: that the thing is such because under certain aspects it can be deciphered as a sign by a structure [...]. There is no reason to think that, if this is the basic biological situation, it would qualitatively change with the phylogenetic 
complication, and that there would be any qualitative jump at the level of that particular biological state that we call 'knowledge'. There could be complications and interdependences such and so obscure as to force a simplification of the issue into existence through the assumption of qualitative jumps, but that which we cover when we move from a progressive seriation of complexity and interdependencies to the admission of radically diverse types of contact with the real is only our ignorance" (Prodi 1976: 70-72).

Prodi knew very well that cellular processes occur by the junction of a key and a lock. But he also knew that the natural universe is full of holes and protrusions, while in the course of evolution some protrusions have chosen some holes and adapted to them, and other possible choices have been eluded. Today we know that nature does not proceed according to economic laws: nature is the place of "megagalactic" and multimillionaire wastefulness, where the right solution is reached, and sets itself as a law, at the expense of millions of attempts doomed to failure. Yet Prodi's problem was exactly that of the dynamic of such a process of waste and choice, absolutely blind, in which, however, some situations, brute in themselves, are established at a certain point as optimal for something that is able to recognize them, or "read" them as preferential.

Undoubtedly, "reading" is a metaphor, and it is a metaphor to say that "the world is made of things that become signs for the suitable readers (for the categories able to read it)" (Prodi $1988^{8}: 41$ ). But Prodi's issue was not to say that in those cases something similar to our "reading" by cultured individuals would occur: his problem was the question whether, by any chance, our ability to read would already be foreshadowed in that blind dialogue that happened between things. Prodi's problem was not finding signs in nature, but identifying nature as the prehistory of the sign: going back in time and in phylogenesis, and asking about the emergence of the sign as a natural fact. Therefore, Prodi's problem was a quest for finding the elementary sign, those processes that certainly are not yet signs, but that are presented as the beginning of a dynamic of interpretation, as the dawn of thirdness not yet emerged, but already prefigured.

However, I may not have made clear the novelty of the approach. Previous attempts consisted of saying: "Cell $A$ speaks as .... It is obvious that if any cell speaks, if any cell interprets, it would be a human being. Prodi jumped from ontogenesis to phylogenesis. He was not interested in the behaviour, certainly stupid, of an actual cell. He was interested in the phylogenetic process through which cells had "learned" to interact. Prodi's question did not concern the behaviour of a single cell but the way in which the biological history emerged. His

8 The manuscript mistakenly says 1968; it should be 1988. 
research was not, like that of the naive semio-geneticists, a semiotics of the cell, but research into evolution as semiosis, that is, about the subterranean and slow evolution of semiosis.

In other words, Prodi was dominated by the thought that if we are as we are, and we are cultural beings, this phenomenon must be rooted in some disposition of the matter. Therefore, he was looking for phylogenetic phantoms of thirdness in order to explain how thirdness begins, knowing that they were hints, beginnings, mumblings. Yet if the human being reaches thirdness, this can happen only if thirdness is already there, inchoative, as it were, lying in ambush, but ready to evolve.

I hold that this approach was new and, as such, it has been welcomed by the world of scholars.

Between 1976 and the beginning of the 1980s, Prodi had a choice: either to test his hypothesis on the molecular level, or to develop it on a molar level. It is clear that he could not have demonstrated it experimentally. If it was a hypothesis concerning natural sciences, he would have had to produce experiments during which it would be shown that a biological event could have remained unoccurred on the basis of an interpretative choice. I do not believe that in the current state of scientific knowledge it is possible to do so; neither are theatrical representations of the behaviour of lymphocytes elaborated by immunologists able to prove that these behave semiosically. Or - but this would be anthropomorphization it was a hypothesis in the field of human sciences. Now, if natural sciences are interpretations of data (given that the "data" are not already the result of an interpretation), human sciences are interpretations of interpretations: an anthropologist elaborates a theory on the social structure of a primitive tribe by asking the local informant why he does a certain thing; an art theoretician elaborates hypotheses about the effects of works of art registering the way in which the works are read. And it is obvious that it is not possible to ask a cell why it behaves how it behaves.

Would developing the hypothesis of elementary cellular semiosis have been possible on the basis of experimental data? In any case, Prodi preferred to broaden his hypothesis by extending it to the universe of moral and aesthetic values and of cultural structures. With such an acceleration - as I have already pointed out elsewhere $^{9}$ - his philosophical production came out at a pace in his last decade that was unthinkable for an author, and even more so for a publisher. Prodi's last books appeared with different publishers because none of them alone could keep up with his productivity. I have spoken - elsewhere - of anxiety, as if Prodi wanted

9 Possibly a reference to an earlier talk by Eco on Prodi - see Eco 1988 b. 
to put an end to a global system of knowledge, of a Hegelian flavour, before a feared event could have impeded it. I do not know whether it is true, I do not know whether Prodi would trust that obscure instinct that the biological has got, and that allows to suggest to the cultural that for which the biological, the place of blind necessity, prepares to plot.

The fact is that Prodi made the choice of transforming his semiotic hypothesis into a 'clavis universalis' ${ }^{10}$, with often brilliant results. I have in mind that page of his last article ${ }^{11}$ where, looking quite dismissively at the various hermeneutics only able to interpret history, and on the basis of the Vichian confidence in verum ipsum factum,${ }^{12}$ he reminds us that any knowledge, any hypothesis, any brick added to the edifice of culture, is nothing but a manifestation of the millenary fact that life is a bending of the matter on itself, reflection, auscultation, folding of matter on its own origins. Therefore, hermeneutics is not a late product of culture, but the same elementary movement of life that is born because something obscurely interprets something else.

Still, going back to my specific disciplinary field, his proposal remains a challenge that I do not think has been welcomed yet in all its implications.

Deducing semiotics from biology, instead of enlightening biology with semiotics, is to say - if I were obliged to use the language of the philosophical texts that, unfortunately, were formative for us - deducing spirit from matter. Yet it is apparent that this dichotomy loses its radical significance from Prodi's unitary point of view. In the act of auscultation of the phylogenetic depth in which we live, Giorgio Prodi manifested his own deep and passionate form of religiosity, and at the same time his elevated and complete humanism.

\section{References $^{13}$}

Eco, Umberto 1988a. On semiotics and immunology. In: Sercarz, Eli E.; Celada, Franco; Michison, N. Avrion; Tada, Tomio (eds.), The Semiotics of Cellular Communication in the Immune System: Proceedings of the NATO Advanced Research Workshop on the Semiotics of Cellular Communication in the Immune System held at Il Ciocco, Lucca, Italy, September 9-12, 1986. (Nato ASI Series 23.) Berlin: Springer, 3-15.

Eco, Umberto 1988b. Una sfida al mito delle due culture. Saecularia nona 2: 46-49. [In English: Eco 1994.]

10 A universal key.

11 Prodi 1988.

12 Giambattista Vico's aphorism "the true is the made" - we can only understand what we have made.

13 The list of references has been added by the editor. 
Eco, Umberto 1994. In memory of Giorgio Prodi: A challenge to the myth of two cultures. (Johnston, Marina, trans.) In: Jaworski, Leda Giannuzzi (ed.), Lo studio bolognese: campi di studio, di insegnamento, di recerca, di divulgazione. (Filibrary series 8.) Stony Brook: Forum Italicum (Center for Italian Studies, State University of New York at Stony Brook), 75-78. Prodi, Giorgio 1974. La preistoria del segno. Lingua e Stile 9(1): 117-146.

- 1976. Le basi materiali della significazione. Versus 13: 69-93.

- 1988. La cultura come ermeneutica natural. Intersezioni: Rivista di storia delle idee 8(1): 23-48. [In English: Prodi 1989.]

- 1989. Culture as natural hermeneutics. In: Koch, Walter A. (ed.), The Nature of Culture. Proceedings of the International and Interdisciplinary Symposium, October 7-11, 1986 in Bochum. (Bochum Publications in Evolutionary Cultural Semiotics; BPX 12.) Bochum: Studienverlag Dr. Norbert Brockmeyer, 215-239. [Translation of Prodi 1988.]

\section{Джорджио Проди и нижний семиотический порог}

Публикация речи Умберто Эко в честь биосемиотика Джорджио Проди (1928-1987) в 1988 году.

\section{Giorgio Prodi ja semiootika alumine lävi}

Tõlkena publitseeritakse Umberto Eco ettekande tekst, mille ta esitas itaalia arstiteadlase, filosoofi ja biosemiootiku Giorgio Prodi (1928-1987) mälestuseks korraldatud üritusel aastal 1988. 